\title{
The Use of PowerPoint (PPT) PiWoCa Technique in the Form of Bubble Map in Helping Year 2 ESL Pupils' Simple Sentence Construction: A Literature Review
}

\author{
Swaran Raj Sahadevan, Maslawati Mohamad* \\ Faculty of Education, Universiti Kebangsaan Malaysia, Bangi, Malaysia \\ Email: *maslawati@ukm.edu.my
}

How to cite this paper: Sahadevan, S. R., \& Mohamad, M. (2020). The Use of PowerPoint (PPT) PiWoCa Technique in the Form of Bubble Map in Helping Year 2 ESL Pupils' Simple Sentence Construction: A Literature Review. Creative Education, 11, 1602-1616.

https://doi.org/10.4236/ce.2020.119117

Received: July 22, 2020

Accepted: September 5, 2020

Published: September 8, 2020

Copyright $\odot 2020$ by author(s) and Scientific Research Publishing Inc. This work is licensed under the Creative Commons Attribution-NonCommercial International License (CC BY-NC 4.0). http://creativecommons.org/licenses/by-nc/4.0/

\section{(c) (i) (8) Open Access}

\begin{abstract}
English language in Malaysia is taught according to the four main skills. They are known as the listening, speaking, reading and writing skills. Writing is classified as the most challenging but a crucial skill to be acquired by pupils as it serves various communicative purposes compared to the other skills. Thus, this paper provides a literature review on the issues and techniques to overcome the obstacles faced by young learners in constructing simple sentences in English. Some contributing factors to pupils' inability of simple sentence constructions are due to pupils' lack of practice, interference of mother tongue and limited vocabulary knowledge. As such, it is essential to address the issues faced by young learners and produce constructive ways in helping young learners to achieve their learning goals precisely. Some of the strategies used by English language teachers in teaching writing skills are by using visual aids in the form of pictures, word cards, bubble map incorporating with technology like PowerPoint presentation within and outside classroom teaching and learning practices. English language teachers could employ one of the strategies which might suit their classroom teaching and learning practices in line with the $21^{\text {st }}$ century learning preferences.
\end{abstract}

\section{Keywords}

English Language Writing Skills, Simple Sentence Construction, Visual Aids, Bubble Map, Technology

\section{Introduction}

Learning is known as a progressive process in life as there is a lot to be discov- 
ered and ventured. Learning becomes meaningful when one is able to understand and produce an outcome with the knowledge gained. The similar principle is applied to language learning. English language is known as a universal language as it is being practiced by people across the globe particularly for business transaction and educational purpose. Acquisition of the English language has been brought to a crucial point as it is the fundamental language to be known in order to progress towards global excellence. In Malaysia, English language is known for its second language as Bahasa Malaysia holds the trademark of National Language. According to Darus and Kaladevi (2009), the mastery of English language can be associated to lifelong learning process as it involves challenging experiences especially for second language learners. English has become the second language after it was first introduced in Malaysia during the colonization period. Presently, it is used as the language of trade in establishing international relationships, exchanging of knowledge, products and technology and thus for various other purposes in life.

According to Brown (as cited in Darus \& Kaladevi, 2009), young learners have to be adequately exposed to four fundamental skills namely listening, speaking, reading and writing in order to master the English language proficiency. However, the standard of English among Malaysian children is on the decline despite learning English for several years (Tan \& Santhiram, 2007). The proficiency among Malaysian pupils is relatively low especially in their writing skills. Pupils still seem to make errors in pertinent aspects of language when it comes to producing their write up. Looking into this aspect, the government has thereby implemented the Integrated Primary School Curriculum (KBSR) and Primary School Standard Curriculum (KSSR) and now known as Common European Framework of References (CEFR) for year one, two, three and four primary school pupils with the aim to equip pupils with the basic language skills to enable them to converse effectively in a variety of scope (MOE, 2013, 2025).

Furthermore, one of the shifts under the Malaysian Education Blueprint 2013-2025 coincides with the study intended to be carried out. In October 2011, the Ministry of Education established an extensive review of the education system in Malaysia in order to form a new National Education Blueprint which assesses the performance of the present Malaysian education system considering the historical starting points with international benchmarks. In that case, it is believed that the use of PPT PiWoCa technique in the form of bubble map could help to realize the $7^{\text {th }}$ Shift in the Malaysian Education Blueprint 2013-2025 which is to "Leverage ICT to scale up quality learning across Malaysia". This shift indicates the importance of maximizing the use of ICT in scaling up the quality of holistic learning regardless of pupils' geographical belonging, capacity and their capability level. As such, the idea of using PowerPoint (PPT), Pictures and Word Cards technique to assist pupils with sentence construction is developed to meet the requirements of the field intended.

English language in Malaysia is taught according to the four main skills. It covers on listening, speaking, reading and writing skills. Writing skill is classified 
as the most challenging skill as compared to the others. Writing is a pertinent skill to be mastered by the pupils in order to acquire the proficiency in the written work (Darus \& Ching, 2009). It is an important skill to be mastered as it helps the learners to put their thoughts and ideas on paper. Besides, the mastery of this skill is vital in exemplifying information precisely. Therefore, this skill should be taught from basic to complex level accordingly. In the primary ESL classroom, the use of English language is generally evident among young learners during the contact hours in school especially when the subject teachers made a point for them to communicate in English during their lesson. This is supported by Musa, Lie and Azman (2012), where children residing in the interior areas tend to get exposed to the language of choice only during their English lesson conducted at school.

Apart from that, short message system, which briefly known as (SMS) language could be one of the hindrances which deficit pupils' writing skill to some point. Being in the era of globalization, almost everything is made easy for mankind with the intervention of salient technology. Pupils learning of the correct usage of English grammar can be affected when "texting language" is widely used among primary and secondary school students. According to Bell, Plester and Wood (2012), generally pupils at primary level have a habit of pinning their thoughts down based on how they converse. Conversational language is considered as informal English and is meant for passing verbal message across as verbal language has a few distinctive differences as compared to a formal written English. Nevertheless, pupils have conformed to abbreviations that indicate meaning for complete words. For example words or phrases like "by the way" abbreviated as "btw", "Be right back" as "brb" and "I know right" as "ikr". Basically, these abbreviations are typed in "code" and functions as brief text only.

Nauert (2012) also stated that the habit of "texting language" could impact pupils' writing of simple sentence structure indirectly when they do not understand the fundamental requirements of a formal written work. At times teachers tend to face difficulty in reading their pupils' work or essays as they could not comprehend what they have written down due to the impact of text languages. The use of abbreviations may not necessarily appear in the text language alone. It can appear from different sources like advertisement, social media, and television which can influence pupils' writing as they are able to grasp any information at quick pace and assume that the information gained is wholly true although their memory span is relatively low (Lutz \& Huitt, 2003). This may result in long term deficiency in pupils' learning of correct English language sentence structure.

\section{Literature Review}

\subsection{Issues Related to ESL Learners' Writing Skills}

Writing is classified as the most challenging component in acquiring the English language proficiency. Kellogg (as cited in Fareed, Ashraf \& Bilal, 2016) opines 
that writing is a psychological process that tests the memory and verbal command to express ideas successfully because sufficient composition of a text indicates successful learning of the second language. However, from the synthesis it is understood that the highest number of errors in the written form of the language was made in grammar in the form word classes, subject-verb agreement, forms of singular and plural, syntax and sentence structures. Adding to it are the spelling and punctuation errors. It also indicates that learners tend to repeat ideas which lax cohesion and execute informal style of writing influenced by the spoken language.

According to Goh (2010) "writing is a system for intrapersonal communication using visible sign or graphics symbols on a flat surface such as paper, cloth or even stone slabs". Every language has its own customized and unique features. We come across various types of writing everyday such as the daily newspaper, advertisements, bills, notice, letters, and so on. However, not everyone is able to write successfully. Fareed, Ashraf and Bilal (2016) have emphasized that writing is a specific skill which helps learners to put their thoughts forward into words in a meaningful form to interact or pass a message to someone. Writing thereby allows learners to practice rules of grammar and examination techniques in order to be proficient in the complex skill.

The major issues with writing among the undergraduate were the correct usage of grammar and syntax. Various reasons like culture, teaching and learning styles and learners themselves contribute to the lack of writing competence in English language. Al-Khairy (as cited in Fareed et al., 2016) indicated the need of qualified, trained and motivated teachers to help in developing the learners' writing skill prominently. Fareed et al. (2016) stated that despite the problems and factors faced by the ESL undergraduates, it is notable that there a few suggestions that can be explored and implemented to improve their writing skills. The fundamental way in improving their writing skills is through sufficient reading and writing practices. Hence, this has actually enlightened the researcher on a few deliberate practices which could be implemented in the study in moulding the pupils' writing.

Singh, Singh, Razak, and Ravinthar (2017) indicated that teaching of writing skills in the ESL classroom is a crucial issue encountered by teachers in Malaysian ESL classrooms. The skill needs to be developed from basic to complex stages. It is suggested if teachers could learn and impose new strategies of teaching the particular skill to capture the learners' interest in learning English especially in acquiring good writing skills. It is believed that teachers need to be equipped with adequate knowledge, skills and strategies in teaching writing skills as it is known for its challenge especially for L2 learners.

Every initiative that teachers take marks a significant milestone in the process of teaching and learning English as to benefit pupils' learning needs. Nunan (as cited in Singh et al., 2017) backed up that the most challenging task in writing is to create a piece of writing which has a good flow with correct usage of the English grammar. Singh et al. (2017) mentioned that "L2 learners at secondary 
school level performed badly in the English language during examinations". It is proven with the results of the SPM (Sijil Pelajaran Malaysia) examination English Paper for 2014 which indicated that $77.3 \%$ of the students passed compared to $80 \%$ in 2013 (The Star Online, 2014). The exam was based on writing. The weaknesses detected in their written work were mainly in the sentence structures produced and also in the thoughts developed as stated by Singh et al. (2017).

In the Malaysian scenario, many studies have prevailed on pupils' grammatical errors in their writing skill. Ghabool and Kashef (2012) revealed that Malaysian ESL students have problems in writing especially in language use like simple sentence construction which covers on subject-verb object and punctuation errors. Learners apparently need consistent support and guidance from the teachers in moulding their writing skills prominently. Besides, teachers will need to assist pupils in terms of reading and correcting their essays and provide responses as for the pupils to rectify their mistakes in their writing. This could help them to improve in the pertinent skill eventually.

Another scenario indicated that learners were too obsessed with the use of their mother tongue when it comes to writing. They tend to think in their native language instead of thinking in English when comes to pinning their thoughts down. Musa et al. (2012) disclosed that the interference of L1 was seen as a barrier for pupils to perform in their writing activities as they needed grammar translation method in order for them to write in English. The error analyses and contrastive analyses were used to obtain information among 120 students in three parts of Malaysia. From the technique applied, it is learned that students tend to struggle when comes to using the correct form of English grammar in their essay writing. Three types of grammatical errors were highlighted. Those errors were found in the misuse of articles, to be verb, and subject-verb agreement precisely. They also concluded that the first language's interference which is the Malay Language in the context of the study was the reason behind students' grammatical errors. Subject-verb agreement and subject-verb object are the most common errors found in sentences constructed by pupils (Singh, Singh, Razak, \& Ravinthar, 2017). It was evident in their written work like examination and exercise books which proves that pupils made such errors due to their inability to include the suitable subject, verb and object resulting in improper sentence construction.

\subsection{Visual Aids in Enhancing the Learning Process}

Visual aids are better known as tools that help to make learning easier and meaningful as it involves the visual senses. A person is able to remember things better upon experiencing it through his or her visions. It also helps in arousing learners' interest and motivation level when it comes to gaining new knowledge and information. This is supported by Singh (as cited in Shabiralyani, Hasan, Hamad, \& Iqbal, 2015) signifying that any device which by sight and sound increases the individual's practice, outside that attained through read labelled as an audio visual aid. It is also one of the instructional devices used in the classroom 
to improve and ease the teaching and learning process. It is one of the fundamental aids to be used in conducting lessons in the classroom teaching and learning practices involving the young learners in acquiring the second language rather prominently.

Kishore (as cited in Shabiralyani et al., 2015) stated that the use of visual aids enhances the teaching and learning process as it stimulates thinking and cognition process. Apart from that, incorporation of visual aids in teaching and learning stirs the cognitive level and caters an authentic learning environment to the learners. It is because pupils tend to have a reliable source to refer to and evidence based on the things they see or listen. Hence, the intervention of visual aids in the form of power point presentation, pictures, word cards and bubble map with the aid of technology into the lesson do impact pupils' level of understanding which leads to achieving their learning goals and needs. Therefore, clear planning and execution of visual aids in the classroom saves time and increase pupils' learning productivity to a certain degree.

\subsection{Pictures in Teaching Sentence Construction}

Pictures constitute the most plentiful, efficient and least expensive medium of teaching. A picture is worth thousands of words. An appropriate image layout serves as a catalyst resulting in many words and an aggregation of creative and logical thinking (Qistha, 2017). As for classroom teaching and learning, the use of pictures as a tool to teach is essential to make the learning meaningful. It also helps to reduce learners' cognitive load by aiding their thought processes. A teacher who incorporates pictures to teach may capture pupils' attention to some extent especially in explaining certain terms and definitions. This approach helps pupils to get involved in learning without many hurdles as it creates a sense of belonging in the classroom.

The use of pictures in teaching writing is productive to some point. It could be used as a starter to gauge learners into the lesson as it could prepare learners towards the learning process. Scott and Ytreberg (as cited in Qistha, 2017) state that pictures as media of teaching are the best known sensory aids. Visualizations are necessary for younger learners because most activities for the pupils should include movements which involve the senses. Hasanah (2015) added that using pictures in teaching simple sentence construction is effective as pupils find it interesting and interactive.

Apart from that, Mee (2014) supported that using picture was proven to be one of the best approaches in teaching and learning of writing in English language classroom especially in primary schools. Colourful representation could arouse and attract pupils' interest and attention towards learning English writing skills regardless of their age. Pictures signify a situation where it assists pupils to learn and construct simple sentences easily as they are able to think something related to the pictures shown. It contributes to the development of language ability and thinking skill which serves to widen experience from their background knowledge. This strategy had elevated pupils' participation in the writing 
activities. Mee (2014) suggested that this study could help educators to seek the effectiveness of teaching writing skills through pictures among lower proficiency pupils' as it also helps to improve their confidence in writing.

\subsection{Word Cards as an Effective Strategy}

Word cards provide an opportunity in learning new vocabulary. From the analysis, study indicates that the use of word cards as a strategy helps to improve vocabulary knowledge to some extent. Word cards are efficient in assisting learning the written form of lexical words receptively and productively. The systematic implementation of word cards in a few studies has helped participants improve the recognition of the grammatical function of the lexical units selected. According to Diaz (2016), the use of word cards was effective than expected as participants showed the highest improvement in this aspect when it comes to acquiring knowledge in the classroom.

The use of word cards should be a mandatory strategy in any beginner English course. According to the results of the study conducted by Diaz (2016), the researcher recommends making word cards for all frequently used lexemes. The use of word cards does help learners' acquisition of new vocabulary effectively which lead them to construct sentences correctly. The new words are very well accepted with the intervening of word cards as it helps to retain the lexical words in the pupils' schemata and makes learning meaningful. It is also known as a significant strategy of aiding pupils learning of spelling, meaning and grammatical function of new words.

Siti and Ani (2018) mentioned that learners can use word cards to learn English to expand their vocabulary knowledge and writing skills. By using word cards consisting of information, as words or numbers, learners will be exposed to ideas in coining them into simple sentences. This is known as one of the effective strategies in helping average or below average ESL primary pupils to construct or write down sentences using the correct structure. This approach can be explored in and outside of the classroom. It is a form of drilling to aid memorization by way of spaced repetition.

Aulia (2018) supported that teaching of simple sentence construction for young learners is a challenging task. It is an important skill to be mastered by pupils in order to be able to express feelings, emotions, and ideas to others in a written form of communication. It can be an evidence that communication is a mutual relationship between the speakers and the listeners or between the writers and the readers. If the listeners or the readers have insufficient knowledge of vocabulary, they may find it difficult to understand the message sent by the speakers or the writers. Thus, the implementation of word cards into the ESL classroom does expose pupils or young learners to choices of words to be learned. This process will in a way expand pupils' vocabulary knowledge and assist them to produce simple sentences to some extent. With this, the idea of merging pictures with word cards in the form of bubble map via PowerPoint slides will serve as a strategy in developing pupils' construction of simple sen- 
tences significantly.

\subsection{The Use of Thinking Map: Bubble Map}

Based on a research conducted by Darus (as cited in Omar, Zubiar, \& Seng, 2016), findings showed that $60 \%$ of Malaysian pupils fail to reach the minimum level of competency to take part efficiently in their thinking and learning process. The results prevail that learners with knowledge were unable to apply their knowledge on practical basis. Thus, the Ministry of Education has come up with an initiative of introducing the $\mathrm{i}$-Think program to the education field. The i-Think program initiated ensures teachers are using thinking maps as an aid to encourage higher order thinking skills in both primary and secondary schools throughout the nation. The Pelan Pembangunan Pendidikan Malaysia (Malaysian Education Development Plan) 2013-2025 emphasizes the concept of higher order thinking skills (HOTS). As such, this is one of the strategies of promoting pupils to activate their thinking caps in solving problems critically.

The i-Think program has three main objectives (Figure 1):

1) Nurture and develop innovative human capital

2) Increase thinking skills amongst children

3) Equip future generations with HOTS

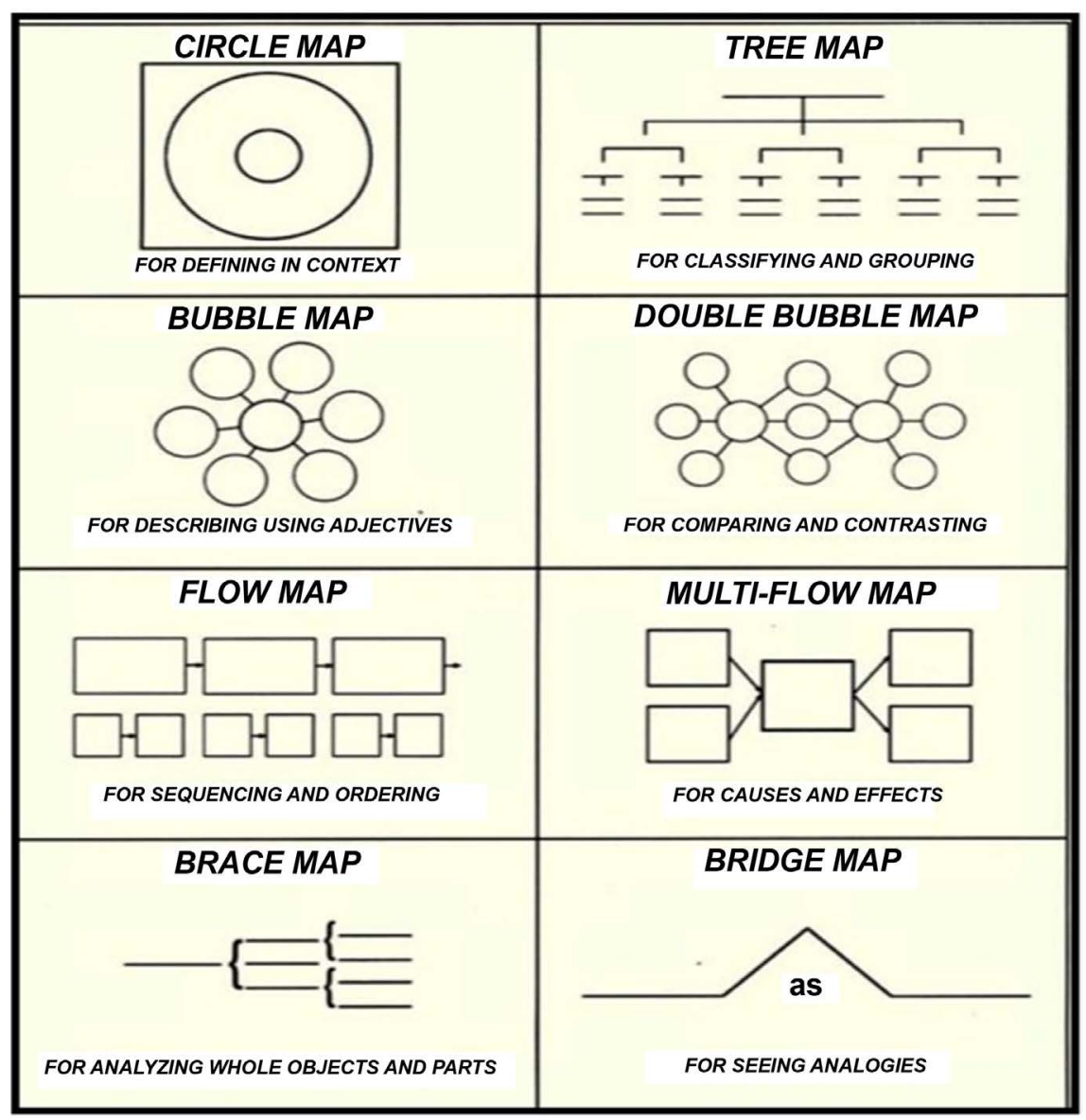

Figure 1. Types of I-THINK maps. 
The I-THINK maps comprises of eight types of visual designs. They are circle map, bubble map, double bubble map, tree map, brace map, flow map, multi flow map and bridge map. For the concern of this study, bubble map is selected to be incorporated to teach pupils on construction of simple sentences. The Bubble Map is usually used to explicate something (objects or things) using adjectival words or phrases. The Bubble Map consists of several circles which are connected by lines. The centre circle is where the topic is written and all the other circles which are connected to the centre elaborate on the topic with appropriate use of vocabularies and phrases. Pupils will be encouraged creatively and critically to think of words to write something related to the subject (Balakrishnan, 2015) (Figure 2).

A current study was conducted by Fan (2016) in Taiwanese elementary school using the idea of thinking maps. The researcher implemented thinking maps to support students' thinking and decision making in the writing program in the elementary school in Taiwan. The circle maps and bubble maps are two of the Thinking Maps that pupils applied in their writing program in two weeks for five times during their teaching and learning process and that apparently assisted them to write better.

As such, the novelty of this study is where a picture will be placed on the centre circle connected with lines of word cards related to the picture in the form of a bubble map. Using the pictures and words presented in the form of bubble map via PowerPoint slides, pupils will be briefed to construct simple sentences related to the topic. This strategy will be helpful for pupils to think critically and make connections. Along the process, pupils will have an opportunity to describe the pictures they see on the slides and brainstorm with their peers. A platform for pupils to interact productively in constructing simple sentences will be created (Figure 3 ).

\subsection{Technology in English Language Teaching and Learning}

Gearing towards global advancement, language acquisition becomes effective with the aid of multimedia as it promotes pupils' progress and learning interest prominently. The use of technology provides a space which facilitates the teaching and learning of English language. Graddol (as cited in Solanki \& Phil, 2016) indicates that technology lies at the heart of globalization where it affects education,

The Bubble map

The bubble map is used for describing things using adjectives. It helps the students to develop their ability to identify qualiies and use descriptive words.

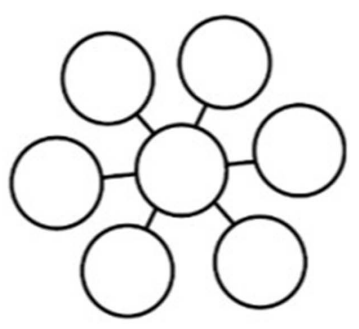

Figure 2. An example of a bubble map. 


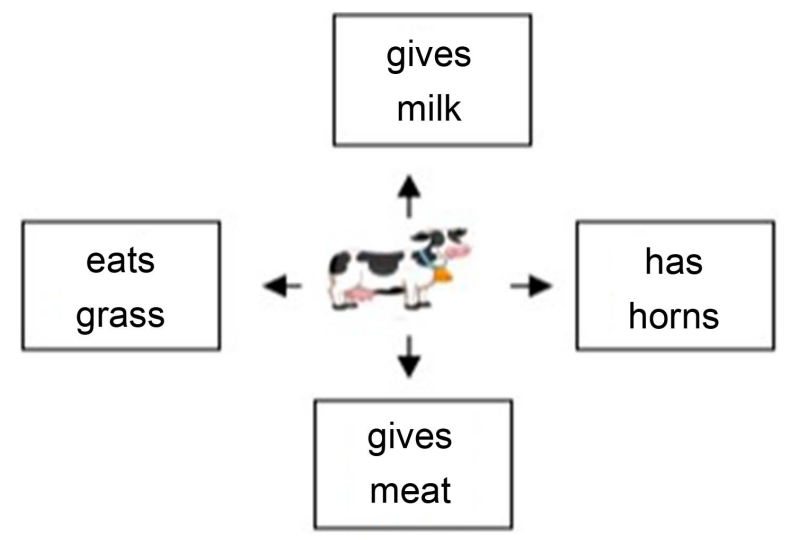

Figure 3. PPT PiWoCa in the form of bubble map.

work and culture. The quality of teaching of English language and pupils' learning can be enhanced with proper usage of the technology and multimedia. However, a few areas of problems in multimedia and technology can be rectified in order to be used effectively in the teaching and learning process. Proper planning and execution may save time and ensure the productivity of learning taking place.

The use of multimedia and technology also helps pupils to be involved and learn according to their interests as it caters to both visual and auditory senses of the learners. The advancement of technology to teaching and learning featuring various learning styles provides a platform for English language exploration in the new era. Therefore, this strategy will be incorporated into this study as it plays a pivotal role in achieving the research objective precisely. Writing may be a difficult skill to be taught but merging with the idea of teaching via PowerPoint presentation may intrigue learners' active involvement in this study. However, PPT courseware alone would not encourage pupils' thinking or English communication in both the speaking and written form (Solanki \& Phil, 2016). Thereby, the learners will be briefed and guided along the teaching and learning process. Scaffolding will be provided to pupils if needed in constructing simple sentences using the aid presented.

Md Yunus et al. (2013) exemplified the advantages and disadvantages of incorporating ICT in teaching ESL reading and writing on 23 secondary school students. The result of the study proves that the use of ICT captivates pupils' attention, facilitate the teaching and learning process, assist in improving students' vocabulary knowledge and promote meaningful learning which were regarded as the most important advantages of using ICT. This study is done in schools where ICT facilities are sufficiently available. Ghazali (2017) stated that the outcome of the study could have been contradicting if this study was conducted in schools where ICT facilities were insufficient. There are also some cases in the rural areas where the ICT facilities are adequate however the Internet connection tends to be quite poor. These are the key factors that need to be taken into consideration when dealing with the use of ICT in the classroom teaching prac- 
tices. On the contrary, this study on PPT PiWoCa does not require the assessment of internet facility as the technique is prepared and executed by teachers in the classroom. Parents who are willing to guide their children in simple sentence construction outside of classroom may retrieve the content from the teachers via a pendrive or disc.

Cognitive learning theories are concerned with "processes which occur inside the brain and nervous system as an individual learns" (Mechlova \& Malcik, 2012). Knowledge is gained and shared when pupils get involved in an active learning environment where the learners take initiative to improve his/her abilities through interaction and collaboration. Internal mental processes cover on inputting, organizing, storing, retrieving, and finding relationships between information. This process leads to latest information being linked to prior or past knowledge. Mechlova and Malcik (2012) stated that an educator should set an example to be the best not only in their fraternity but also willing to take up new challenges and be prepared with updated knowledge in facing changes in the education line. As such, the use of PowerPoint (PPT) PiWoCa technique in the form of bubble map is believed to be in line with pupils' learning interest as it fits into current development of Malaysian classroom teaching practices as well.

Studies declare that teachers' competency is a factor that influences the use of ICT in the classroom practices. This refers to the ICT skills needed by a teacher in serving the $21^{\text {st }}$ century learning. If a teacher possesses the essential skills, he/she will find it convenient to engage technology during their teaching practices (Mwunda, 2014). As for this study, exploration of the digital age especially in executing the technique to help pupils in constructing simple sentences correctly is essential for teachers to be well equipped. Therefore, it is vital for teachers to have sufficient access to ICT facilities like laptops and power point software in carrying out this strategy of teaching the young learners as to captivate their focus in learning to construct simple sentences.

Karthigesu and Mohamad (2020) stated that it is important that the current generation of pupils is groomed with the $21^{\text {st }}$ century skills, attitude and knowledge beyond horizon in order to assure that only technologically literate and critically thinking manpower are joining the competitive global market. Hence, latest educational technologies and strategies are being smartly adopted by teachers and policy makers. Malaysian Education Blueprint 2013-2025 under Shift 7 has stated that incorporation of ICT in education allows for more customized and purposeful learning. With that, ICT could be explored in various ways during teaching and learning practices to promote self-paced and independent learning among pupils which in a way correlates with the intervening of PPT PiWoCa technique in the form of bubble map in helping pupils to construct simple sentences prominently.

\subsection{Preferences of the $21^{\text {st }}$ Century Learners}

The $21^{\text {st }}$ century is a century of globalization where teaching and learning is ex- 
pected to serve the $21^{\text {st }}$ century learners. A few elements are embedded under these preferences of the $21^{\text {st }}$ century learners. Learning and innovation skills which include mastering diverse knowledge and skills, critical thinking and problem-solving and communication and collaboration are highlighted as one the first elements. Second, skills of digital literacy include information literacy, media literacy, and ICT literacy. Third, career and life skills include flexibility and adaptability, initiative, social and cultural interaction, productivity and accountability, and leadership and responsibility (Trilling \& Fadel as cited in Lase, 2019).

Lase (2019) stated that today, individuals aged 18 and 23, known as Generation Z (Gen Z) have evolved due to the technological advancements. They are the generation who welcomes challenges and prefers group discussions through interactive learning environment and media where learning could be done anywhere and anytime. This generation gives priority to active collaboration and discussion with their team or peer when it comes to gaining knowledge. Lase also added that the use of digital tools and online learning is in line with the current trend being integrated into pupils' learning process as Gen $\mathrm{Z}$ learners are very much into digital tools and expect assess with least barriers. Siti (2019) supported that the advancement of technology in teaching and learning can enhance and capture the interest of learners to participate in the learning process. Thus, this further indicates that the use of PPT PiWoCa technique in the form of bubble map could help pupils in construction of simple sentences as it covers the necessary factors in catering to the $21^{\text {st }}$ century learning styles and preferences.

\section{Conclusion and Implications}

In conclusion, this paper provides a literature review of the challenges and techniques to overcome the obstacles faced by young learners in constructing simple sentences in English. Various factors that inhibit the learners writing proficiency were discussed. However, the importance of mastering the writing skills was also discussed with relevant strategies and intervention especially in catering to the $21^{\text {st }}$ century learners' preferences.

The essential factors which inhibit pupils' writing skills highlighted will be able to provide clarity to future educators and researchers in understanding the young learners' problem significantly. At the same time, necessary techniques and approaches engaged by English language educators in teaching the writing skills especially simple sentence construction among these learners are identified based on past studies and researches. By identifying the approaches employed by other educators, English educators could engage one of the strategies which might suit their classroom teaching and learning practices.

Some implications could be derived from this paper which could benefit the ESL teachers and learners. Necessary considerations should be taken by teachers in addressing the challenges faced by young learners during the classroom teaching and learning practices. Appropriate teaching techniques can be em- 
ployed by educators in aiding learners' learning styles and patterns. Finally, ESL educators should also convey the importance of acquiring good writing skills to learners for them to have an insight into it as they serve to various communicative purposes.

\section{Conflicts of Interest}

The authors declare no conflicts of interest regarding the publication of this paper.

\section{References}

Aulia, I. (2018). Using Flashcards for Teaching English Vocabulary in ELT Classroom. https://www.academia.edu/38230585/Using_Flashcards_for_Teaching_EnglishVocabul ary_in_ELT_Classroom.pdf

Balakrishnan, V. (2015). Thinking Maps in Moral Education. In International Conference on Moral Education APNME 2014 (pp. 1-15). University of Malaya. http://eprints.um.edu.my/13029

Bell, V., Plester, B., \& Wood, C. (2012). Spelling and Text Language Are Influenced by Technology.

http://www.examiner.com/article/spelling-and-text-language-are-influenced-by-techno logy

Darus, S., \& Ching, H. K. (2009). Comman Errors in Written English Essays of Form One Chinese Students: A Case Study. European Journal of Social Sciences, 2, 243-253.

Darus, S., \& Kaladevi, S. (2009). Error Analysis of the Written English Essays of Secondary School Students in Malaysia: A Case Study. European Journal of Social Sciences, 8 , 483-495.

Diaz, J. L. C. (2016). Word Cards: An Effective or an Obsolete Strategy to Learn the Spelling, Meaning and Grammatical Function of New Vocabulary. Journal of Education and Language, 26, 59-76. https://doi.org/10.15517/pa.v16i26.25190

Fan, Y. S. (2016). Thinking Maps in Writing Project in English for Taiwanese Elementary School Student. Journal of Educational Research, 4, 36-57.

https://doi.org/10.13189/ujer.2016.040106

http://www.hrpub.org

Fareed, M., Ashraf, A., \& Bilal, M. (2016). ESL Learners Writing Skills: Problems, Factors and Suggestion. Journal of Education and Social Sciences, 4, 81-92. https://doi.org/10.20547/jess0421604201

Ghabool, N., \& Kashef, S. H. (2012). Investigating Malaysian ESL Students' Writing Problems on Conventions, Punctuation, and Language Use at Secondary School Level. Journal of Studies in Education, 2, 130-143. https://doi.org/10.5296/jse.v2i3.1892 https://www.researchgate.net/publication/259935742

Ghazali, N. (2017). The Perceptions of Form Four Students on the Usage of Google + towards Improving ESL Writing Skills. Master's Thesis, Bandar Baru: Faculty of Education, University Kebangsaan Malaysia.

Goh, L. (2010). Message Me Please: An Action Research on Using Message Cards to Encourage Writing. In Asia Pacific Educational Research Association Conference (pp. 115-137). HELP University. https://www.researchgate.net/publication/260165617

Hasanah, H. U. (2015). Teaching Grammar Using Pictures.

http://iteslj.org/Techniques/Saricoban 
Karthigesu, K., \& Mohamad, M. (2020). Primary School Teachers' Perceptions on the Integration of Interactive Whiteboard (IWB) during Reading Instructions. International Journal of Academic Research in Business and Social Sciences, 10, 722-741. https://doi.org/10.6007/IJARBSS/v10-i2/6977

Lase, H. (2019). Education and Industrial Revolution 4.0. https://www.researchgate.net/publication/334837153

Lutz, S., \& Huitt, W. (2003). Information Processing and Memory: Theory and Applications. Educational Psychology Interactive. Valdosta, GA: Valdosta State University. http://www.edpsycinteractive.org/papers/infoproc.pdf

Md Yunus, M., Nordin, N., Salehi, H., Sun, C. H., \& Embi, M. A. (2013). Pros and Cons of Using ICT in Teaching ESL Reading and Writing. International Education Studies, 6, 119. https://doi.org/10.5539/ies.v6n7p119

Mechlova, E., \& Malcik, M. (2012). ICT in Changes of Learning Theories. In International Conference on Emerging e-Learning Technologies and Applications (pp. 1-70). University of Nairobi.

https://www.researchgate.net/publication/261335480_ICT_in_changes_of_learningthe ories/link/0f31753690d5621535000000/download

Mee, R. W. (2014). Pictures as a Tool for Sentence Construction. Journal of American Research Thoughts, 1, 311-323. http://www.researchthoughts.us

MOE Ministry of Education, Malaysia (2013). Malaysia Education Blueprint 2013: Preliminary Report 2013-2025.

http://www.moe.gov.my/en/pelan-pembangunan-pendidikan-malaysia-2013-2025

Musa, N. C., Lie, K. Y., \& Azman, H. (2012). Exploring English Language Learning and Teaching in Malaysia. Journal of Language Studies, 12, 35-52.

Mwunda, N. M. (2014). A Framework for Integration of ICTs in Teaching and Learning Processes in Secondary Schools in Machakos Sub-County. Master's Thesis, Nairobi: School of Computing and Informatics, University of Nairobi.

Nauert, R. (2012). Texting May Undermine Language, Spelling Skills. http://psychcentral.com/news/2012/07/29/texting-may-undermine-language-spelling-s kills/42309.html

Omar, A., Zubiar, H. A., \& Seng, G. H. (2016). Teachers' Implementation of the I-Think Program in the ESL Classroom: A Case Study. International Journal of Science Arts and Commerce, 1, 33-45.

Qistha, F. M. (2017). The Effectiveness of Using Pictures in Developing Sentence Writing Skills for the Seventh Graders in the Governmental Schools in Rafah. Master's Thesis, Gaza: Department of Curricula and Teaching Methods, Al-Azhar University of Gaza.

Shabiralyani, G., Hassan, K. S., Hamad, N., \& Iqbal, N. (2015). Impact of Visual Aids in Enhancing the Learning Process Case Research; District Dera Ghazi Khan. Journal of Education and Practice, 6, 226-233.

Singh, C. K. S., Singh, A. K. J., Razak, N. Q. A., \& Ravinthar, T. (2017). Grammar Errors Made by ESL Tertiary Students in Writing. English Language Teaching, 10, 16. https://www.researchgate.net/publication/316028867

Siti (2019). Technological Advancements in Education 4.0. The Online Journal of Distance Education and e-Learning, 7, 63-69. http://www.tojdel.net

Siti, \& Ani (2018). Teaching Vocabulary Using Flashcard to Young Learner. Journal of English Education, 1, 775-782. https://doi.org/10.22460/project.vli6.p775-782

Solanki, D. S., \& Phill, M. (2016). Use of Technology in English Language Teaching and Learning: An Analysis. In International Conference on Language, Medias and Culture 
(Vol. 33, pp. 150-156). Singapore: IACSIT Press.

Tan, Y. S., \& Santhiram, R. (2007). Problems and Challenges of Learning through Second Language. Journal of Malaysian Research, 25, 29-54.

The Star Online (2014). Kulasegaran: SPM Results 2014: Overall Performance Takes a Dip. http://www.thestar.com.my/news/nation/2015/03/03/spm-results-down 